\title{
AlHA and Pancytopenia as Complications of Pembrolizumab Therapy for Metastatic Melanoma: A Case Report
}

\author{
Dan $\mathrm{Ni}^{\mathrm{a}}$ Fatmah AlZahrani ${ }^{\mathrm{b}}$ Michael Smylie $^{\mathrm{c}}$ \\ aFaculty of Medicine and Dentistry, University of Alberta, Edmonton, AB, Canada; \\ ${ }^{b}$ Faculty of Medicine, Division of Dermatology, Edmonton, AB, Canada; ${ }^{\circ}$ Faculty of \\ Medicine, Oncology Department, Cross Cancer Institute, Edmonton, AB, Canada
}

\section{Keywords}

AlHA $\cdot$ Immunotherapy $\cdot$ Metastatic melanoma $\cdot$ Pancytopenia $\cdot$ Pembrolizumab

\begin{abstract}
Immunotherapy has been an emerging treatment for metastatic melanoma and several other malignancies since 2015. Hematological immune-mediated adverse effects from immunotherapy are rarely reported but they can cause serious harm to patients. Antibodies such as ipilimumab, nivolumab and pembrolizumab target different immune checkpoints to promote $T$ cell anti-tumour response. In particular, pembrolizumab is an antibody that inhibits programmed cell death receptor 1 (PD-1) to upregulate tumour suppression. In this report, we present a case of pembrolizumab-induced autoimmune hemolytic anemia and pancytopenia in a patient who was receiving pembrolizumab treatment for metastatic melanoma. This patient has a history of chronic lymphocytic leukemia and was diagnosed with metastatic melanoma in 2017. He developed symptomatic AlHA and pancytopenia after receiving 8 cycles of pembrolizumab in 2018. Pembrolizumab treatment was discontinued and he was treated with blood transfusion and prednisone. After 5 months of tapering prednisone treatment, his
\end{abstract}




\section{Case Reports in Oncology}

anemia and pancytopenia have improved toward successful recovery. Cancer patients already face an increased risk of immunosuppression with conventional chemotherapy. This case report also summarized all reported cases of PD-1 inhibitor hematological adverse effects in the treatment of oncological diseases. These incidents reflect the risk of immune-mediated hematologic adverse effects, which should be considered in all patients using immunotherapy.

(C) 2019 The Author(s)

Published by S. Karger AG, Basel

\section{Introduction}

Immunotherapy has emerged as one of the hot topics of cancer treatment since the approval of ipilimumab in 2011, and subsequently PD-a inhibitors. There are several categories of immunotherapy: monoclonal antibodies, non-specific immunotherapies, oncolytic virus therapy, T-cell therapy, and cancer vaccines, some of which are still in the clinical trial phase [1-4]. Monoclonal antibodies play a large role in the treatment of metastatic melanoma by serving as checkpoint inhibitors to promote $\mathrm{T}$ cell activation and upregulate $\mathrm{T}$ cell antitumor responses to suppress tumours. Since 2015, the US Food and Drug Administration (FDA) has approved three checkpoint inhibitor drugs for the treatment of metastatic melanoma, each inhibitor targeting different "brakes" of the T-cell activation pathway. Ipilimumab targets the cytotoxic T-lymphocyte antigen 4 (CTLA-4), while pembrolizumab and nivolumab target the programmed cell death receptor 1 (PD-1). Somatic mutations in melanoma are associated with presentation of cancer-specific antigens, and these antigens appeared to be the target for checkpoint inhibitor-reactivated immune cells [5]. Immunotherapy for metastatic cancer is not without its downfalls; the activated immune cells may also produce autoimmune reaction against healthy cells in different organs. Immune mediated adverse events have been reported and each immunotherapeutic drug seem to have distinctly different adverse effects, for example, gastrointestinal adverse effects are commonly reported in ipilimumab but not in pembrolizumab or nivolumab [6]. As immunotherapy can affect a whole range of systems in the body, it is necessary for physicians to document and report adverse events. In this case, we present one of the first reported case of pembrolizumab-induced pancytopenia and autoimmune hemolytic anemia (AIHA).

\section{Case Report}

A 67-year-old male with a past medical history of chronic lymphocytic leukemia (CLL) , and diagnosed BRAF negative metastatic melanoma in 2017 on pembrolizumab as first line treatment was presenting with shortness of breath. He presented to his medical oncology follow-up on his 8th cycle of the pembrolizumab with 1 week history of worsening fatigue and shortness of breath initially on exertion and then at rest. Routine laboratory investigations showed a hemoglobin of $66 \mathrm{~g} / \mathrm{L}$ that morning at the end of June, which was quite a decrease from his baseline hemoglobin of $154 \mathrm{~g} / \mathrm{L}$ as well as normal LDH (Fig. 1). The patient was sent to the emergency department to be assessed by hematology. He received a $1 \mathrm{~g}$ dose of methylprednisone IV and red cell transfusion. Supportive management was done. Investi- 


\section{Case Reports in Oncology}

gations showed that his absolute reticulocyte count was $12.8 \times 10^{-9} / \mathrm{L}(N=20-90)$ (Fig. 2). Peripheral blood film reflected normocytic anemia and no spherocytic hemolysis were seen on smear. Bone marrow biopsy found bone marrow involvement by the low-grade B-cell lymphoma and reduced and left shifted erythropoiesis, and the biopsy did not reflect red cell aplasia at the time.

Two weeks later, His hemoglobin was $83 \mathrm{~g} / \mathrm{L}$, white cell count $4.2 \times 10^{-9} / \mathrm{L}(\mathrm{N}=4.5-11)$, platelets $45 \times 10^{-9} \mathrm{~L}(N=150-450)$, ANC $1.5 \times 10^{-9} \mathrm{~L}(1.5-8 \mathrm{~L})$ (Fig. 1). Due to the continued anemia, neutropenia and thrombocytopenia, the medical team decided to start him on prednisone at a dose of $1 \mathrm{mg} / \mathrm{kg} /$ day.

The hematologist suspected two components to his symptoms: PD-1 inhibitor use in the background of CLL. As a result he developed an evolving to aplastic anemia, with a component of autoimmune hemolytic anemia.

Two months after the emergency visit, he was followed up by the hematologist that noted bone marrow suppression - which was slowing recovering given the rising reticulocyte count and hemolytic anemia; likely autoimmune given positive direct antiglobulin test (DAT) and response to prednisone.

Two weeks into his prednisone taper, there was a rise in his LDH and haptoglobin so the team extended the prednisone duration. When his prednisone taper was finished in October, his WBC was $13.3 \times 10^{-9} / \mathrm{L}$, hemoglobin $112 \mathrm{~g} / \mathrm{L}$, platelet $220 \times 10^{-9} / \mathrm{L}$, and lymphocyte $8.8 \times$ $10^{-9} /$ L (Fig. 1). He was found to have an enlarging pulmonary nodule and a referral was in put for stereotactic radiation. He continued to have weekly CBCs to monitor for anemia. He restarted on prednisone twice for a decrease in his hemoglobin as soon as tapering is attempted.

\section{Discussion}

In our case report, we have a 67-year-old male with pre-existing CLL who was found to have anemia, thrombocytopenia and neutropenia after 8 cycles of pembrolizumab, an antiPD-1 immunotherapy, for his metastatic melanoma. He was diagnosed with autoimmune hemolytic anemia (AIHA) based on positive DAT result and positive response to prednisone. Pancytopenia due to aplastic anemia was also diagnosed based on hypocellular finding on bone biopsy. After discontinuation of pembrolizumab and treatment with blood transfusion and ongoing steroids, he is responded appropriately with rising RBC and reticulocyte count.

The cause of AIHA is idiopathic for a majority of patients. Other causes include drugs, malignancy, autoimmune disorders, and infections [19]. The diagnostic criteria include a positive DAT, laboratory finding supporting hemolysis such as increase in serum lactate dehydrogenase (LDH), and reticulocytosis and spherocytosis on peripheral blood smears [20].

Acquired pancytopenia can be caused by decreased production of cells, or by pooling and destruction of cells. Production of cells can be decreased by leukemia, aplastic anemia, nutritional deficiency, bone metastasis, fulminant sepsis, and myelodysplastic syndrome. Pooling/destruction of cells can be caused by splenomegaly, paroxysmal nocturnal hemoglobinuria, or acquired hemophagocytic lymphohistiocytosis [21].

There have been several reported cases of drug induced AIHA or pancytopenia due to pembrolizumab since anti-CTLA-4 and anti-PD-1 immunotherapies were approved by the FDA in 2011. 


\section{Case Reports in Oncology}

To this date, pembrolizumab has three reported cases of hematologic adverse effect from the treatment of different cancers. In 2016, Nair et al. reported AIHA with pure red cell aplasia after 3 cycles of pembrolizumab for malignant melanoma; In 2017, Atwal et al. reported pancytopenia after 18 cycles of pembrolizumab. In 2018, Ogawa et al. reported exacerbation of AIHA after 1 cycle of pembrolizumab treatment for lung adenocarcinoma. In these cases, recovery from anemia was achieved with the use of a combination of steroids, IVIG, RBC transfusion, and platelet transfusion [7-9]. A summary of adverse effects of PD-1 inhibitors used in patients with melanoma can be found in Table 1.

Nivolumab, the other anti-PD-1 antibody therapy, has similar reports of adverse hematologic reaction. There is a total of eleven cases to date detailing either AIHA or pancytopenia as the adverse reaction. Only $5 / 11$ of the patients resolved their anemia or pancytopenia with steroid and transfusion, and the remaining six patients either expired from their pre-existing illness before anemia improved, or still have persistent pancytopenia with bone marrow failure. In 2017, Michot et al. described three patients who had unresolved anemia, one of which died from febrile neutropenia from abdominal sepsis [15]. In 2016, Palla et al. described a patient who was refractory to steroid therapy and died due to her cancer before the AIHA can be corrected [14]. In 2018, Tokumo et al. also described a patient who died from progression of lung cancer after onset of pancytopenia before he could resolve his pancytopenia [18]. A summary of adverse effects of PD-1 inhibitors used in patients with other malignancies can be seen in Table 2.

Pembrolizumab and nivolumab are antibodies that binds to PD-1 receptors to block the PD-1 receptor pathway, a pathway that leads to the downregulation of immune reactions to tumours. As a result, anti-PD-1 antibodies will reverse T-cell suppression and induce anti-tumour responses.

It is suggested that the blockade of PD-1 will enhance the T-effector cells in tissues and tumour microenvironments [22]. Studies have also shown an association between the inhibition of PD-1 pathway and increase in B cell activity and cytokine level [23, 24]. Hemolysis in our case can be explained by activation of pre-existing RBC specific T-effector cells or B cells by the anti-PD-1 antibodies. In addition to peripheral origins for cytopenia (AIHA and autoimmune thrombocytopenia), Michot et al. in 2017 found bone marrow failure in 3 cases of nivolumab therapy for melanoma, suggesting a central origin for immune-related cytopenia in bone marrow suppression as well [15].

Our case is one of the first ever reported case of drug induced AIHA and pancytopenia due to pembrolizumab. In our patient, hemolytic anemia and aplastic anemia due to bone marrow suppression were both present, suggesting PD-1 antibodies can affect RBC counts both peripherally and centrally.

Our patient does have chronic lymphocytic leukemia, and it is possible that the cytopenia is attributed to a masked progression to CLL. However, the CLL was stable and the patient did not have signs of CLL progression prior to the initiation of pembrolizumab treatment. Lymphocytosis was present in the lab work taken at baseline and after his symptoms emerged.

Although adverse effects were noted, re-challenging with the same PD-1 inhibitor can yield different results. Khan et al. re-challenged a patient with ipilimab and nivolumab, and patient redeveloped AIHA [16]. Conversely, Tardy et al. re-challenged a patient with nivolumab without recurrence of AIHA [17]. The mechanism by which autoimmune hemolysis is activated needs further studies. 
Reported hematologic toxicities are rare but they can be fatal for pembrolizumab. These reports demonstrate the potential hematologic toxicity of immunotherapy, and they call for increased monitoring for the safety of patients, and familiarity with the rescue treatment for pancytopenia and AIHA caused by PD-1 inhibitors.

\section{Conclusion}

Cancer patients face greater risk of immunosuppression with standard chemotherapy treatment compared to the general population. With the advance of immunotherapy for metastatic melanoma and other malignancies, a number of immuned-related AIHA and pancytopenia have been reported with PD-1 inhibitors. Physicians should be aware of the risk of hematologic toxicity and immunosupression when they prescribe immunotherapy, and execise appropriate monitoring to optimize patient safety.

\section{Availability of Data and Materials}

The datasets used and/or analysed during the current study are available from the corresponding author on reasonable request.

\section{Statement of Ethics}

Informed consent was obtained from patient.

\section{Disclosure Statement}

The authors declare that they have no competing interests.

\section{Funding Sources}

Not applicable.

\section{Author Contributions}

DN interpreted the patient data and was a major contributor in writing the manuscript. FA and MS obtained, analyzed and interpreted the patient data, and were major contributors in editing the manuscript. All authors read and approved the final manuscript. 


\section{References}

1 Yang Y. Cancer immunotherapy: harnessing the immune system to battle cancer. J Clin Invest. 2015 Sep;125(9):3335-7.

2 Fukuhara H, Ino Y, Todo T. Oncolytic virus therapy: A new era of cancer treatment at dawn. Cancer Sci. 2016 Oct;107(10):1373-9.

3 Miliotou AN, Papadopoulou LC. CAR T-cell therapy: a new era in cancer immunotherapy. Curr Pharm Biotechnol. 2018;19(1):5-18.

4 Butterfield LH. Cancer vaccines. BMJ. 2015 Apr;350 apr22 14:h988.

5 Snyder A, Makarov V, Merghoub T, Yuan J, Zaretsky JM, Desrichard A, et al. Genetic basis for clinical response to CTLA-4 blockade in melanoma. N Engl J Med. 2014 Dec;371(23):2189-99.

6 Abdel-Wahab N, Shah M, Suarez-Almazor ME. Adverse events associated with immune checkpoint blockade in patients with cancer: a systematic review of case reports. PLoS One. 2016 Jul;11(7):e0160221.

7 Nair R, Gheith S, Nair SG. Immunotherapy-associated hemolytic anemia with pure red-cell aplasia. N Engl J Med. 2016 Mar;374(11):1096-7.

8 Atwal D, Joshi KP, Ravilla R, Mahmoud F. Pembrolizumab-induced pancytopenia: a case report. Perm J. 2017;21:17-004.

9 Ogawa K, Ito J, Fujimoto D, Morita M, Yoshizumi Y, Ariyoshi K, et al. Exacerbation of autoimmune hemolytic anemia induced by the first dose of programmed death-1 inhibitor pembrolizumab: a case report. Invest New Drugs. 2018 Jun;36(3):509-12.

10 Deltombe C, Garandeau C, Renaudin K, Hourmant M. Severe allograft rejection and autoimmune hemolytic anemia after anti-PD1 therapy in a kidney transplanted patient. Transplantation. 2017 Sep;101(9):e291.

11 Kong BY, Micklethwaite KP, Swaminathan S, Kefford RF, Carlino MS. Autoimmune hemolytic anemia induced by anti-PD-1 therapy in metastatic melanoma. Melanoma Res. 2016 Apr;26(2):202-4.

12 Khan U, Ali F, Khurram MS, Zaka A, Hadid T. Immunotherapy-associated autoimmune hemolytic anemia. J Immunother Cancer. 2017 Feb;5(15):15.

13 Yuki A, Takenouchi T, Takatsuka S, Ishiguro T. A case of pure red cell aplasia during nivolumab therapy for cardiac metastatic melanoma. Melanoma Res. 2017 Dec;27(6):635-7.

14 Palla AR, Kennedy D, Mosharraf H, Doll D. Autoimmune hemolytic anemia as a complication of nivolumab therapy. Case Rep Oncol. 2016 Nov;9(3):691-7.

15 Michot JM, Vargaftig J, Leduc C, Quere G, Burroni B, Lazarovici J, et al. Immune-related bone marrow failure following anti-PD1 therapy. Eur J Cancer. 2017 Jul;80:1-4.

16 Schwab KS, Heine A, Weimann T, Kristiansen G, Brossart P. Development of hemolytic anemia in a nivolumab-treated patient with refractory metastatic squamous cell skin cancer and chronic lymphatic leukemia. Case Rep Oncol. 2016 Jun;9(2):373-8.

17 Tardy MP, Gastaud L, Boscagli A, Peyrade F, Gallamini A, Thyss A. Autoimmune hemolytic anemia after nivolumab treatment in Hodgkin lymphoma responsive to immunosuppressive treatment. A case report. Hematol Oncol. 2017 Dec;35(4):875-7.

18 Tokumo K, Masuda T, Miyama T, Miura S, Yamaguchi K, Sakamoto S, et al. Nivolumab-induced severe pancytopenia in a patient with lung adenocarcinoma. Lung Cancer. 2018 May;119:21-4.

19 Chaudhary RK, Das SS. Autoimmune hemolytic anemia: from lab to bedside. Asian J Transfus Sci. 2014 Jan;8(1):5-12.

20 Park SH. Diagnosis and treatment of autoimmune hemolytic anemia: classic approach and recent advances. Blood Res. 2016 Jun;51(2):69-71.

21 Sharma R, Nalepa G. Evaluation and management of chronic pancytopenia. Pediatr Rev. 2016 Mar;37(3):101-11.

22 Agata Y, Kawasaki A, Nishimura H, Ishida Y, Tsubata T, Yagita H, et al. Expression of the PD-1 antigen on the surface of stimulated mouse T and B lymphocytes. Int Immunol. 1996 May;8(5):765-72.

23 Nishimura H, Minato N, Nakano T, Honjo T. Immunological studies on PD-1 deficient mice: implication of PD1 as a negative regulator for B cell responses. Int Immunol. 1998 0ct;10(10):1563-72.

24 Thibult ML, Mamessier E, Gertner-Dardenne J, Pastor S, Just-Landi S, Xerri L, et al. PD-1 is a novel regulator of human B-cell activation. Int Immunol. 2013 Feb;25(2):129-37. 


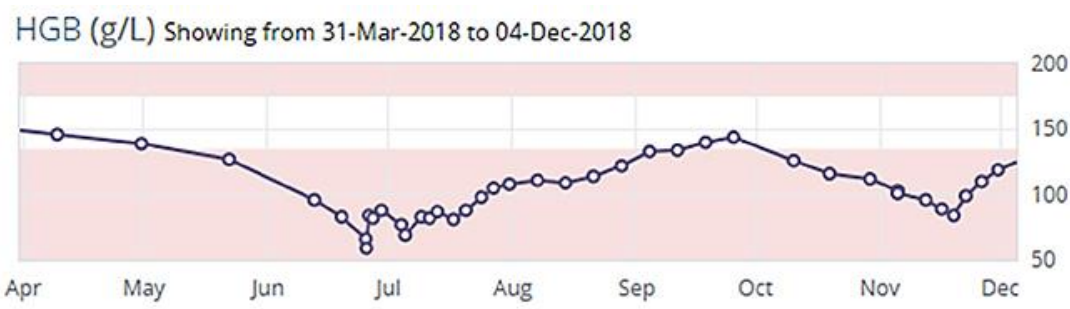

PLT (10**9/L) Showing from 31-Mar-2018 to 04-Dec-2018

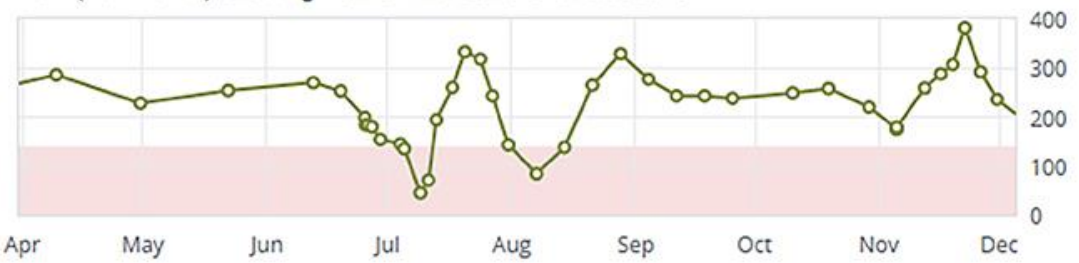

WBC $(10 * * 9 / \mathrm{L})$ Showing from 31-Mar-2018 to 04-Dec-2018

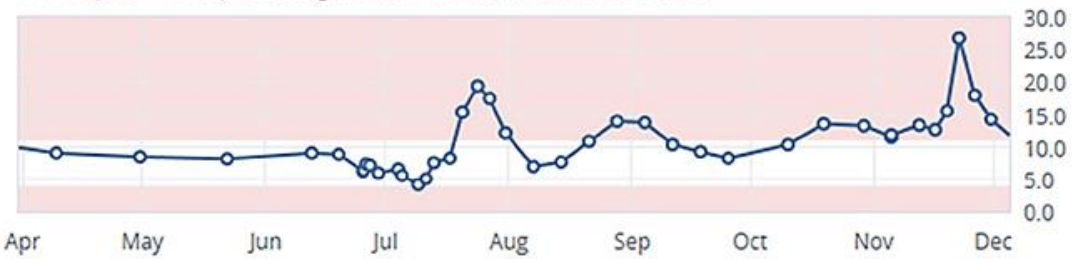

NEUT (10**9/L) Showing from 31-Mar-2018 to 04-Dec-2018

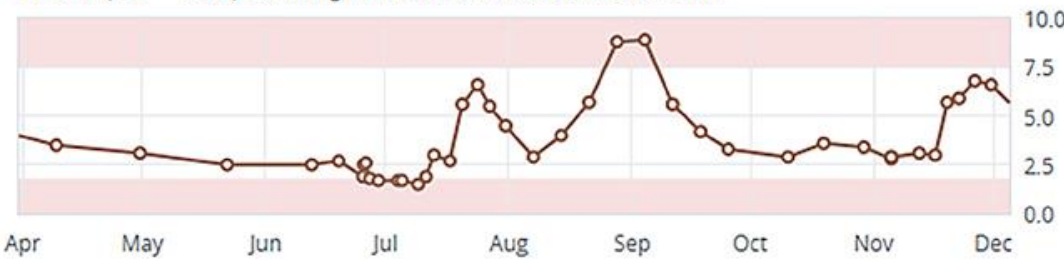

Fig. 1. Course of hemoglobin, platelets, WBC, and neutrophils from July to December after presentation to ER for shortness of breath. 
AlHA and pancytopenia from pembrolizumab use in metastatic melanoma

RETIC\% (\%) Showing from 25-Jun-2018 to 28-Dec-2018

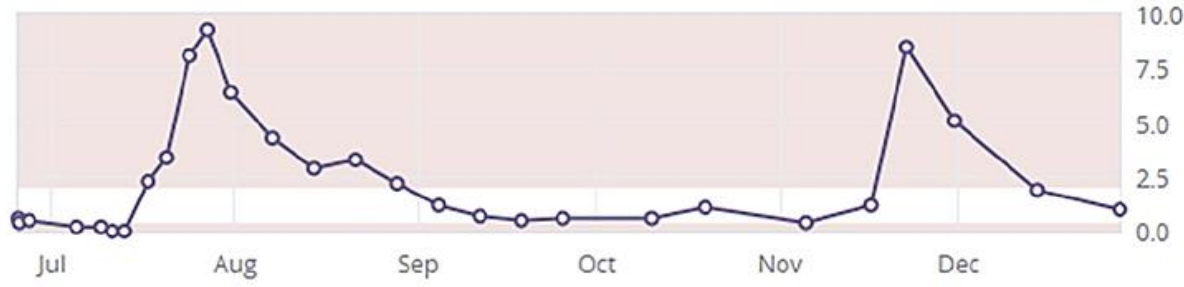

RETIC ABSOLUTE (10**9/L) Showing from 25-Jun-2018 to 28-Dec-2018

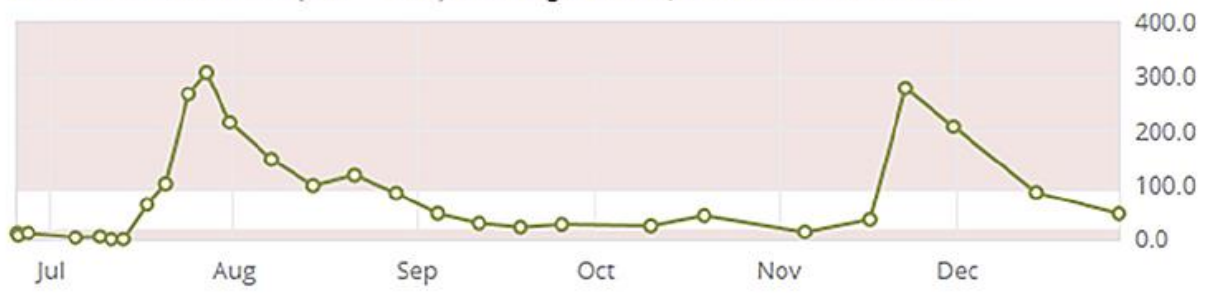

Fig. 2. Course of reticulocyte percentage and absolute reticulocyte count from June to December after presentation to ER for shortness of breath. 
Table 1. Case reports of patients with metastatic melanoma who received PD-1 inhibitor and had adverse hematologic reaction [7-12]

\begin{tabular}{|c|c|c|c|c|c|c|}
\hline & Nair [7], 2016 & Atwal [8], 2017 & Ogawa [9], 2018 & Deltombe [10], 2017 & Kong [11], 2016 & Khan [12], 2017 \\
\hline Diagnosis & $\begin{array}{l}\text { AIHA with pure } \\
\text { red cell aplasia }\end{array}$ & Pancytopenia & AIHA & AIHA & AIHA & AIHA \\
\hline $\begin{array}{l}\text { Age, years/ } \\
\text { gender }\end{array}$ & $52 / \mathrm{F}$ & $52 / \mathrm{F}$ & $82 / \mathrm{M}$ & $73 / \mathrm{M}$ & $85 / \mathrm{M}$ & $43 / \mathrm{F}$ \\
\hline $\begin{array}{l}\text { Pre-existing } \\
\text { comorbidities }\end{array}$ & & & $\begin{array}{l}\text { Hypothyroidism, } \\
\text { chronic anemia but no } \\
\text { hemolysis before treat- } \\
\text { ment of pembrolizumab }\end{array}$ & Kidney transplant & $\begin{array}{l}\text { Severe mitral regurgi- } \\
\text { tation, paroxysmal afib, } \\
\text { hypercholesterolemia }\end{array}$ & $\begin{array}{l}\text { Hyperthyroidism, } \\
\text { smoking }\end{array}$ \\
\hline $\begin{array}{l}\text { Indication } \\
\text { for PD-1 } \\
\text { inhibitor }\end{array}$ & $\begin{array}{l}\text { Malignant melanoma with } \\
\text { LN involvement }\end{array}$ & Metastatic melanoma & lung adenocarcinoma & $\begin{array}{l}\text { Metastatic melanoma } \\
15 \text { mth post kidney } \\
\text { transplant }\end{array}$ & Metastatic melanoma & $\begin{array}{l}\text { Metastatic } \\
\text { melanoma }\end{array}$ \\
\hline $\begin{array}{l}\text { Cycles of } \\
\text { PD-1 } \\
\text { inhibitor }\end{array}$ & $\begin{array}{l}3 \text { cycle of } \\
\text { pembrolizumab }\end{array}$ & $\begin{array}{l}18 \text { cycles of pembrolizumab } \\
(2 \mathrm{mg} / \mathrm{kg}) \text { Q3week }\end{array}$ & $\begin{array}{l}1 \text { cycle of pembroli- } \\
\text { zumab ( } 200 \mathrm{mg} / \text { body) }\end{array}$ & $\begin{array}{l}2 \text { cycles of nivolumab } \\
(3 \mathrm{mg} / \mathrm{kg}) \text { Q } 4 \text { weeks }\end{array}$ & $\begin{array}{l}5 \text { cycles of nivolumab Q } \\
2 \text { weeks }\end{array}$ & $\begin{array}{l}2 \text { cycles of } \\
\text { ipilimumab and } \\
\text { nivolumab }\end{array}$ \\
\hline $\begin{array}{l}\text { Past } \\
\text { treatment } \\
\text { and } \\
\text { immuno- } \\
\text { therapies }\end{array}$ & $\begin{array}{l}\text { Local resection + LN re- } \\
\text { section, adjuvant radia- } \\
\text { tion therapy, } 1 \text { month of } \\
\text { high dose IV interferon; } \\
\text { Local resection again; } \\
\text { ipilimumab resulted in } \\
\text { autoimmune hepatitis; } \\
\text { Pembrolizumab started } \\
\text { for bilateral pelvic } \\
\text { lymphadenopathy }\end{array}$ & $\begin{array}{l}2 \text { cycles of ipilimumab, } \\
2 \text { doses of infliximab }\end{array}$ & $\begin{array}{l}\text { Chemoradiation } \\
\text { therapy }\end{array}$ & $\begin{array}{l}\text { Prior to the nivolumab, } \\
\text { immunosuppression was } \\
\text { reduced. Tacrolimus was } \\
\text { switched to everolimus } \\
\text { ( } 2.5 \mathrm{mg} \text { /day) after the dx }\end{array}$ & $\begin{array}{l}6 \text { cycles of dacarbazine } \\
\text { followed by } 4 \text { cycles of } \\
\text { ipilimumab at } 3 \mathrm{mg} / \mathrm{kg} \\
\text { Q } 3 \text { weeks before } \\
\text { nivolumab }\end{array}$ & $\begin{array}{l}\text { Whole brain } \\
\text { radiation therapy } \\
\text { before starting the } \\
\text { immunotherapy }\end{array}$ \\
\hline Treatment & Prednisone and IVIG & $\begin{array}{l}\text { Steroids, IVIG, RBC and } \\
\text { platelet transfusion }\end{array}$ & $\begin{array}{l}\text { Steroids and RBC } \\
\text { transfusion }\end{array}$ & Steroids & $\begin{array}{l}\text { Steroids and RBC trans- } \\
\text { fusion }\end{array}$ & $\begin{array}{l}\text { First AIHA episode: } \\
\text { RBC transfusion and } \\
\text { steroids Second AIHA } \\
\text { episode: steroid plus } \\
\text { rituximab }\end{array}$ \\
\hline $\begin{array}{l}\text { Clinical } \\
\text { course }\end{array}$ & $\begin{array}{l}\text { Acute anemia occurred } \\
\text { after } 3 \text { doses; Excellent } \\
\text { response to glucocorti- } \\
\text { coid over slow taper over } \\
6 \text { weeks; When predni- } \\
\text { sone was tapered to } 20 \\
\text { mg/day, the pure red cell } \\
\text { aplasia flare and IVIG was } \\
\text { given to enable the taper- } \\
\text { ing of steroids; Hgb and } \\
\text { ret count remained } \\
\text { normal after treatment }\end{array}$ & $\begin{array}{l}\text { Bone biopsy before steroid } \\
\text { and IVIG tx showed hypo- } \\
\text { cellular for age ( } 20 \% \\
\text { cellularity); } 6 \text { weeks after } \\
\text { the course of IVIG revealed } \\
\text { normocellular bone } \\
\text { marrow for age ( } 40 \% \\
\text { cellularity) with erythroid } \\
\text { predominance; Blood cell } \\
\text { counts improved greatly, } \\
\text { although remaining lower } \\
\text { than normal }\end{array}$ & $\begin{array}{l}\text { Admitted } 17 \text { days after } \\
\text { first dose of pembroli- } \\
\text { zumab; Diagnosed with } \\
\text { exacerbation of pre- } \\
\text { existing AIHA induced } \\
\text { by pembrolizumab } \\
\text { therapy; discharged } 34 \\
\text { days from first dose of } \\
\text { pembrolizumab }\end{array}$ & $\begin{array}{l}\text { Presented with AIHA and } \\
\text { acute renal failure due to } \\
\text { kidney rejection } 25 \text { days } \\
\text { after last dose; AIHA } \\
\text { resolved within } 1 \text { week } \\
\text { after steroid treatment } \\
\text { and cessation of } \\
\text { nivolumab; Patient kidney } \\
\text { rejection not resolved } \\
\text { with steroid and patient } \\
\text { returned to dialysis }\end{array}$ & $\begin{array}{l}\text { Presented with AIHA } \\
\text { within } 8 \text { weeks of } \\
\text { nivolumab treatment; } \\
\text { Good response to } \\
\text { steroids. AIHA resolved } \\
\text { in } \sim 2 \text { weeks }\end{array}$ & $\begin{array}{l}\text { AIHA presented } 3 \text { weeks } \\
\text { after last dose of therapy; } \\
\text { Anemia improved over } 2 \\
\text { months with treatment; } \\
\text { Once her Hgb normalized, } \\
\text { she was re-challenged with } \\
\text { ipilimumab and nivolumab } \\
\text { and developed AIHA again; } \\
\text { Anemia improved with } 4 \\
\text { weeks treatment of } \\
\text { steroids and rituximab }\end{array}$ \\
\hline Outcome & $\begin{array}{l}\text { Recovery from anemia; } \\
\text { follow-up CT showed } \\
\text { progression of her } \\
\text { disease with new liver } \\
\text { metastases }\end{array}$ & $\begin{array}{l}\text { Recovered from anemia } \\
6 \text { weeks later; Blood cell } \\
\text { counts still lower than } \\
\text { normal but doing fairly } \\
\text { well at time of writing }\end{array}$ & $\begin{array}{l}\text { Recovery from anemia. } \\
33 \text { days after discharge } \\
\text { patient died from } \\
\text { bacterial pneumonia }\end{array}$ & $\begin{array}{l}\text { Recovery from anemia } \\
\text { Patient died from } \\
\text { melanoma dissemination } \\
3 \text { months later }\end{array}$ & Recovery from anemia & Recovery from anemia \\
\hline $\begin{array}{l}\text { Caveats/ } \\
\text { other } \\
\text { causes }\end{array}$ & & & & & $\begin{array}{l}\text { Patient had positive } \\
\text { DAT in } 2011 \text { and nega- } \\
\text { tive DAT in } 2012 \text { before } \\
\text { starting nivolumab; Not } \\
\text { history of hemolysis } \\
\text { nor other autoimmune } \\
\text { disease }\end{array}$ & \\
\hline
\end{tabular}


Table 2. Case reports of patients with other malignancies who received PD-1 inhibitor and had adverse hematologic reaction [13-16]

\begin{tabular}{|c|c|c|c|c|c|c|}
\hline & Yuki [13], 2017 & Palla [14], 2016 & Michot [15], 2017* & Michot [15], 2017* & Michot [15], 2017* & Schwab [16], 2017 \\
\hline Diagnosis & $\begin{array}{l}\text { Pure red cell } \\
\text { aplasia }\end{array}$ & AIHA & $\begin{array}{l}\text { Pancytopenia/ } \\
\text { Immune related } \\
\text { aplastic anemia }\end{array}$ & $\begin{array}{l}\text { Pancytopenia/ } \\
\text { Immune related aplastic } \\
\text { anemia }\end{array}$ & $\begin{array}{l}\text { Pancytopenia/ } \\
\text { Immune related aplastic } \\
\text { anemia }\end{array}$ & AIHA \\
\hline $\begin{array}{l}\text { Age, years/ } \\
\text { gender }\end{array}$ & $70 / F$ & $70 / \mathrm{M}$ & $73 / \mathrm{F}$ & $70 / \mathrm{M}$ & $78 / \mathrm{M}$ & $82 / \mathrm{M}$ \\
\hline $\begin{array}{l}\text { Indication for } \\
\text { PD-1 inhibitor }\end{array}$ & $\begin{array}{l}\text { Cardiac metastatic } \\
\text { melanoma }\end{array}$ & $\begin{array}{l}\text { Metastatic } \\
\text { lung cancer }\end{array}$ & $\begin{array}{l}\text { Lung } \\
\text { adenocarcinoma }\end{array}$ & $\begin{array}{l}\text { Lung } \\
\text { adenocarcinoma }\end{array}$ & $\begin{array}{l}\text { Lung } \\
\text { adenocarcinoma }\end{array}$ & Metastatic SCC of skin \\
\hline $\begin{array}{l}\text { Cycles of PD-1 } \\
\text { inhibitor }\end{array}$ & $\begin{array}{l}31 \text { cycles of nivolumab } \\
(2 \mathrm{mg} / \mathrm{kg}) \mathrm{Q3} \text { week }\end{array}$ & $\begin{array}{l}2 \text { cycles of nivolumab } \\
(3 \mathrm{mg} / \mathrm{kg})\end{array}$ & $\begin{array}{l}12 \text { cycles of nivolumab } \\
(3 \mathrm{mg} / \mathrm{kg}) \mathrm{Q} 2 \text { week }\end{array}$ & $\begin{array}{l}10 \text { cycles of nivolumab } \\
(3 \mathrm{mg} / \mathrm{kg}) \mathrm{Q} 2 \text { week }\end{array}$ & $\begin{array}{l}1 \text { cycle of nivolumab } \\
(3 \mathrm{mg} / \mathrm{kg}) \mathrm{Q} 2 \text { week }\end{array}$ & $\begin{array}{l}8 \text { cycles of nivolumab } \\
(3 \mathrm{mg} / \mathrm{kg}) \mathrm{Q} 2 \text { week }\end{array}$ \\
\hline Treatment & $\begin{array}{l}\text { steroids and RBC } \\
\text { transfusion }\end{array}$ & $\begin{array}{l}\text { Steroids and RBC } \\
\text { transfusion }\end{array}$ & $\begin{array}{l}\text { RBC and platelet } \\
\text { transfusions; IVIG, Abx }\end{array}$ & $\begin{array}{l}\text { RBC and platelet } \\
\text { transfusion; Granulocyte } \\
\text { colony-stimulating factor, } \\
\text { steroids }\end{array}$ & $\begin{array}{l}\text { Steroids, IVIG, GCF, Abx, } \\
\text { RBC and platelet } \\
\text { transfusions }\end{array}$ & Steroids \\
\hline $\begin{array}{l}\text { Clinical } \\
\text { course }\end{array}$ & $\begin{array}{l}31 \text { cycles later, hospital- } \\
\text { ized for severe anemia } \\
\text { and cardiac failure; } \\
\text { Anemia responsive to } \\
\text { steroids; cardiac failure } \\
\text { caused by severe anemia } \\
\text { was improved with } \\
\text { blood transfusions; } \\
\text { Anemia was resolved }\end{array}$ & $\begin{array}{l}\text { Admitted } 3 \text { days after } \\
\text { second dose; Dx of } \\
\text { AIHA was made; } \\
\text { Patient was refractory } \\
\text { to the steroid therapy } \\
\text { and died due to resp } \\
\text { failure }\end{array}$ & $\begin{array}{l}\text { Pancytopenia/ } \\
\text { aplastic anemia pre- } \\
\text { sented after } 6.2 \text { months } \\
\text { from first nivolumab } \\
\text { treatment; No response } \\
\text { to IVIG. Bone marrow } \\
\text { failure protracted; Died } \\
1 \text { month after from } \\
\text { febrile neutropenia }\end{array}$ & $\begin{array}{l}\text { Pancytopenia/aplastic } \\
\text { anemia presented after } \\
5.4 \text { months from first } \\
\text { nivolumab treatment; } \\
\text { Transient response to } \\
\text { steroids. Bone marrow } \\
\text { failure protracted; } \\
\text { Persistent pancytopenia } \\
\text { still ongoing at } 4 \text { months }\end{array}$ & $\begin{array}{l}\text { Pancytopenia/ } \\
\text { aplastic anemia occurred } \\
0.5 \text { month after first } \\
\text { nivolumab treatment; } \\
\text { No response to steroids } \\
\text { or IVIG; Bone marrow } \\
\text { failure; No resolution of } \\
\text { anemia. Died } 3 \text { month } \\
\text { after from ACS }\end{array}$ & $\begin{array}{l}\text { Hemolysis stopped and } \\
\text { peripheral blood count } \\
\text { stabilized after } 2 \text { weeks of } \\
\text { terminating nivolumab } \\
\text { and treating with } \\
\text { prednisolone }\end{array}$ \\
\hline Outcome & $\begin{array}{l}\text { Recovery from anemia; } \\
\text { No recurrence of ane- } \\
\text { mia; Good quality of life } \\
\text { one year after cessation } \\
\text { of nivolumab and CT } \\
\text { showed only mild } \\
\text { enlargement of cardiac } \\
\text { metastasis for her } \\
\text { melanoma }\end{array}$ & $\begin{array}{l}\text { Unresolved anemia } \\
\text { Patient continues to } \\
\text { have problem with } \\
\text { afib, later develop sig- } \\
\text { nificant resp distress; } \\
\text { Did not want to be } \\
\text { intubated and eventu- } \\
\text { ally expired }\end{array}$ & $\begin{array}{l}\text { Unresolved pancytope- } \\
\text { nia. patient died } 1 \\
\text { month later from febrile } \\
\text { neutropenia associated } \\
\text { with abdominal sepsis }\end{array}$ & $\begin{array}{l}\text { Persistent pancytopenia } \\
\text { still ongoing at } 4 \text { months }\end{array}$ & $\begin{array}{l}\text { Patient died } 3 \text { months } \\
\text { later from acute coronary } \\
\text { syndrome without } \\
\text { resolution of aplastic } \\
\text { anemia }\end{array}$ & $\begin{array}{l}\text { Recovery from anemia; } \\
\text { No signs of tumor } \\
\text { progression }\end{array}$ \\
\hline
\end{tabular}

other

causes 